\title{
Moyamoya Disease with Posterior Communicating Artery Aneurysm: A Case Report
}

\author{
Posterior Komünikan Arter Anevrizmasıyla Moyamoya Hastalığz: \\ Bir Olgu Sunumu
}

\author{
Luo QI, Yu JINLU \\ First Hospital of Jilin University, Department of Neurosurgery, Changchun, China
}

Corresponding Author: Yu JINLU / E-mail: jinluyu@hotmail.com

\begin{abstract}
In moyamoya disease (MMD), subsequent aneurysm in the proximal part of the posterior communicating artery (PcomA) is extremely rare. We report the case of a middle-aged female patient with MMD, who presented with a ruptured wide-necked aneurysm at the proximal part of the developed PcomA that converged with the posterior cerebral artery (PCA) and supplied the distal area. Endovascular treatment was performed, but the stent-assisted coil embolization resulted in occlusion of the internal carotid artery (ICA) above the ophthalmic artery and PcomA. Due to good compensatory collateral circulation, the patient was improved after surgery and had no complications. One-year followup DSA did not show recurrence of the aneurysm. The right ICA was still embolized, but with good compensatory collateral circulation. We conclude that, for an MMD patient with an aneurysm at the proximal part of the developed PcomA, if the ICA and PcomA are accidentally occluded, then the patient may still have a good prognosis due to sufficient collateral blood circulation.
\end{abstract}

KEYWORDS: Moyamoya disease, Posterior communicating artery, Aneurysm

\section{öz}

Moyamoya hastalığında posterior komünikan arterin proksimal kısmında daha sonra anevrizma gelişmesi son derece nadirdir. Moyamoya hastalığı olan ve posterior komünikan arterin proksimal kısmında, posterior serebral arterle birleşip distal bölgeyi besleyen kısımda rüptüre olmuş geniş boyunlu bir anevrizmayla gelen bir hastayı bildiriyoruz. Endovasküler tedavi yapılmış ama stent yardımlı sarmal embolizasyonu oftalmik arter ve posterior komünikan arter üzerinde internal karotid arter oklüzyonuyla sonuçlanmıştır. İyi kompansatuar kollateral dolaşım sayesinde hasta cerrahiden sonra iyileşmiş ve komplikasyon olmamıştır. DSA ile bir yıl sonraki takip, anevrizma nüksü göstermemiştir. Sağ internal karotid arter hala embolize durumdadır ve iyi kompansatuar kollateral dolaşım vardır. Gelişmiş posterior komünikan arterin proksimal kısmında anevrizması olan bir moyamoya hastasında, internal karotid arter ve posterior komünikan arter yanlışlıkla tıkanırsa hastanın yeterli kollateral kan dolaşımı sayesinde hala iyi bir prognozu olabileceğini bildiriyoruz.

ANAHTAR SÖZCÜKLER: Moyamoya hastalığı, Posterior komünikan arter, Anevrizma

\section{INTRODUCTION}

MMD occurs when the distal end of the ICA undergoes progressive occlusion. Subsequent aneurysm formation in the proximal part of the various branches connected to the intracranial ICA is extremely rare (12). However, if the PcomA is not occluded, it can dilate and converge with the posterior cerebral artery, supplying cerebral collateral circulation to the remote area. Eventually, the PcomA will suffer from too much blood flow, possibly resulting in the formation of an aneurysm (7). Expansion of the PcomA with aneurysm after MMD formation is rare, and only a few cases have been reported $(1,8,9,10)$. Therefore, study on the treatment and prognosis of this condition has been limited. Here, we describe the case of a female MMD patient with a wide-necked aneurysm in the proximal part of the PcomA.

\section{CASE REPORT}

\section{1- Medical History and Examination}

A 53-year-old, female patient with severe headache was admitted. She had a history of hypertension for 17 years. Physical examination revealed a stiff neck. Computed tomography (CT) examination revealed a subarachnoid hemorrhage $(\mathrm{SAH})$. Digital subtraction angiography (DSA) showed MMD. The right PcomA was dilated and converged with the PCA. At the proximal part of the PcomA, a wideneck aneurysm was found (Figure 1A, B). The ophthalmic artery of the left ICA was normal (Figure 1C). Vertebral artery angiography revealed that the PCA was massively developed, and supplied the anterior circulation through the posterior choroidal artery (Figure 1D). External carotid angiography revealed anastomosis formation between the intracranial and extracranial arteries. On the basis of these imaging findings, stent-assisted coil embolization was planned. 


\section{2-Operative Procedure and Outcome}

Under general anesthesia, three-dimensional DSA reconstruction showed a $4.1 \mathrm{~mm} \times 2.8 \mathrm{~mm}$ PcomA aneurysm with a neck width of $3.7 \mathrm{~mm}$. The right ICA vasospasm was significant. A stent was delivered, and the opening of the aneurysm was covered. Then, a 3D coil was released, followed by 3 coils. DSA after embolization showed that the aneurysm was trapped, and the ICA blood flow was reduced significantly. After removal of the microcatheter, part of a coil protruded into the PcomA (Figure 2A). DSA showed that the ICA was occluded above the ophthalmic artery level due to thrombosis (Figure 2B). Therefore, urokinase was immediately
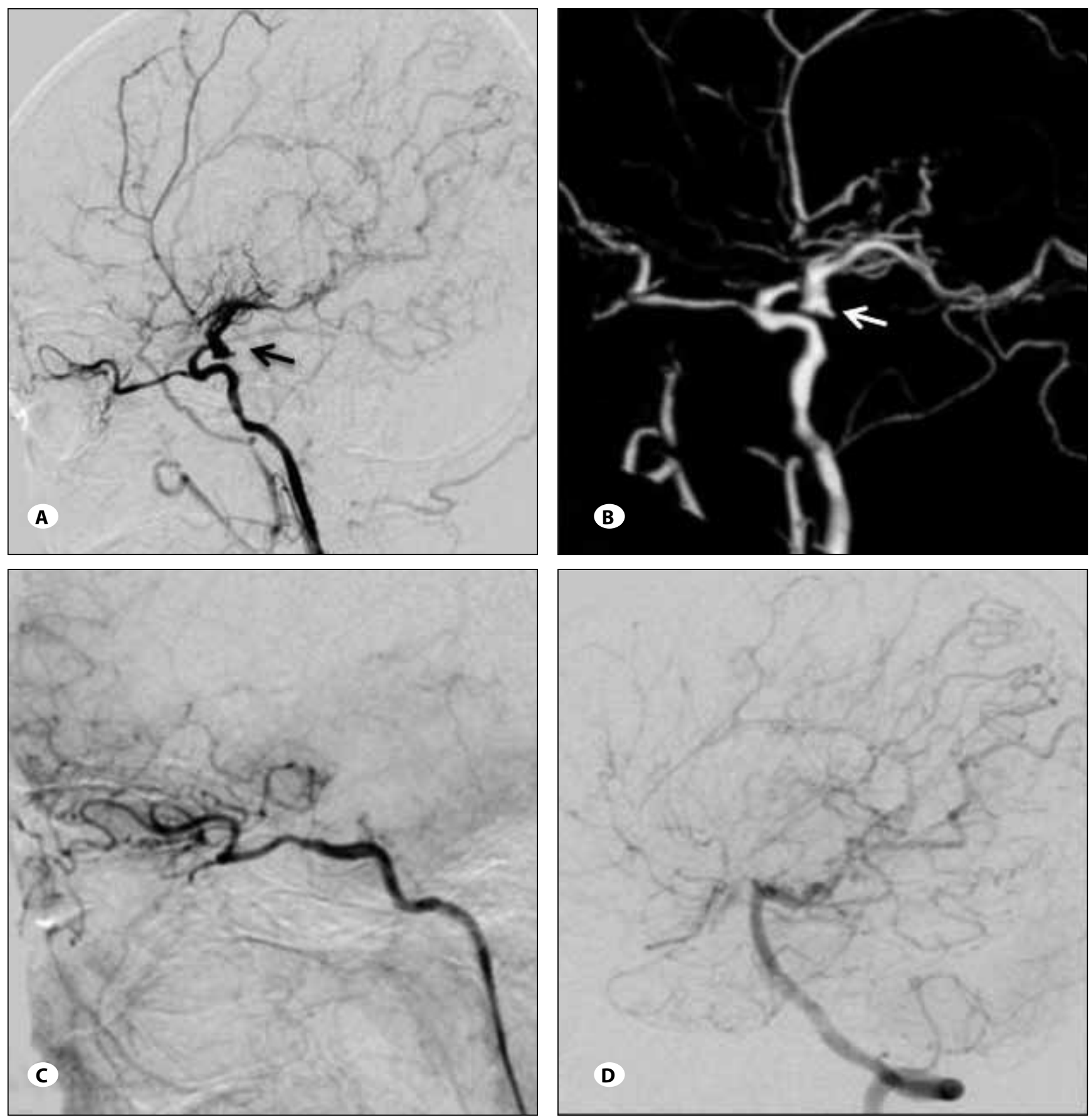

Figure 1: A-B) DSA and 3-D reconstruction of the PcomA aneurysm showed a wide-neck aneurysm in the anterior portion of the PcomA. The right ICA contraction was significant (arrow). C) The left ICA above the ophthalmological artery was normal. D) Vertebral artery angiography showed that the PCA was massively developed, and supplied the frontal circulation through the posterior choroidal artery. 


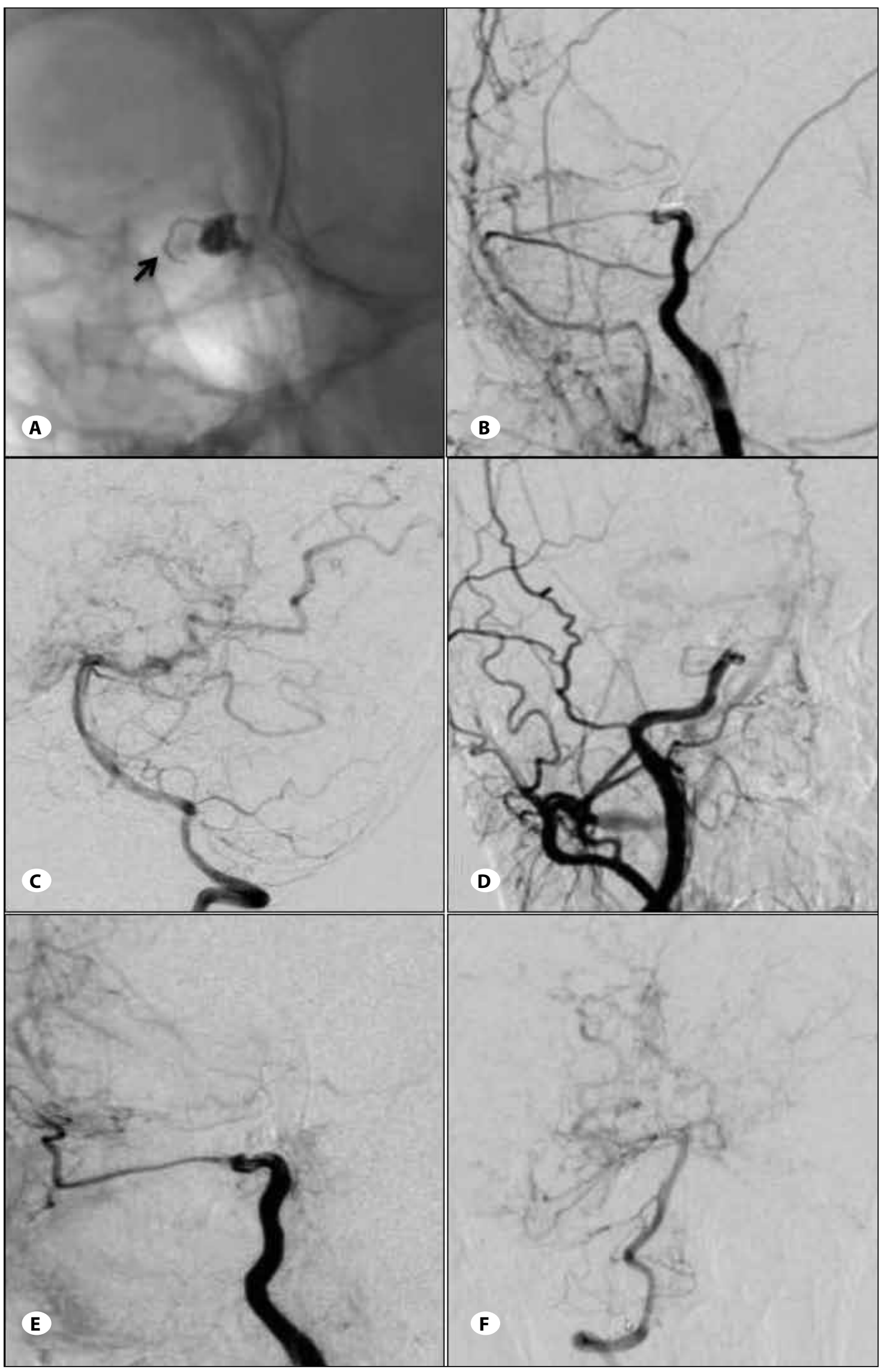

Figure 2: A) After microcatheter removal, some coils remained in the PcomA (arrow). B) Angiography showed that the ICA was occluded above the ophthalmic artery level.

C) Vertebral and carotid artery angiography results revealed a good compensatory collateral circulation. D-F) Follow-up imaging showing no aneurysm and continued embolization of the right ICA. Good compensatory collateral circulation was observed. 
administered and a microwire was used to unobstruct the artery; however, this strategy was ineffective. However, vertebral artery and carotid artery angiography revealed a good compensatory collateral circulation (Figure 2C). After surgery, the patient reported feeling well and was given clopidogrel and aspirin to prevent further thrombosis. One year after surgery, the patient had no SAH recurrence. No aneurysm was seen in DSA imaging. The right ICA was still occluded, but with good compensatory collateral circulation (Figure 2D-F).

\section{DISCUSSION}

When MMD occurs, blood flow in the ICA progressively decreases, and the distal end of the ICA eventually becomes occluded. For these reasons, subsequent aneurysm formation in PcomA is extremely rare. This type of aneurysm is believed to be more developed than other types of aneurysms, presumably due to the compensatory expansion of PcomA and the formation of extensive collateral circulation (11). The present case study reports a middle-aged woman with MMD and a ruptured PcomA aneurysm. The patient was in Suzuki Stage 3 or 4 (2). The DSA results showed compensatory expansion of the PcomA circulation and supply to the frontal circulation by the posterior choroidal artery.

In a study of 107 cases of MMD, Morioka et al. found that 15 cases (7\%) displayed compensatory expansion of the PcomA out of 214 cerebral hemispheres. These cases were associated with bleeding, but were not necessarily associated with PcomA aneurysm (7). However, Satoh et al. reported a case of MMD associated with bilateral PcomA aneurysm, in which the aneurysms did not rupture during the 2-year follow-up period. MMD progressed and the ICA was occluded, resulting in involvement of the bilateral PcomA and disappearance of the PcomA aneurysms (9). Adams et al. reported one case of MMD with PcomA aneurysm. With conservative treatment, the patient suffered from $\mathrm{SAH}$ at the 3-year follow-up (1).

Endovascular techniques, such as coil embolization, are greatly beneficial in treating aneurysms associated with MMD. The greatest benefit of endovascular treatment is the prevention of direct invasion of the brain and Moyamoya vessels $(3,5)$. The aneurysm in this study, which was located in the proximal part of the PcomA with compensatory expansion, eventually ruptured. Although it is possible that such aneurysms may disappear on their own, because the ICA blood flow will decrease gradually until there is complete occlusion, ruptured aneurysms carry a high risk of rebleeding (4). Moreover, it is not practical to wait for natural regression. The time required to wait poses a high risk of patient mortality. Such aneurysms, therefore, should be promptly treated.

Preoperative DSA showed a greatly dilated PCA that supplied the frontal circulation through the posterior choroidal artery. DSA also revealed formation of anastomosis between the external carotid artery system and intracranial arteries. 'Smoke-like' blood vessels were observed. These results suggest that the ICA, assisted by the basilar artery, performed a limited blood-supplying role. Because of the sufficient collateral blood supply, sacrificing the PcomA to close the aneurysm should not cause serious complications. Planned endovascular treatment was performed with stent angiography and embolization. However, even after aggressive thrombolytic therapy, the ICA remained occluded above the ophthalmic artery and PcomA. Due to the good compensatory collateral circulation, the patient showed improvement after surgery and had no complications.

Although the patient showed no complications, this was a lucky case with good collateral circulation. When the aneurysm is located in the frontal circulation in MMD, more emphasis must be placed on endovascular treatment. As the frontal circulation vessels (including the ICA) are very narrow in MMD, they cannot withstand any ischemia resulting from endovascular treatment. The results of the present case study indicate that ischemic complications can occur when the stent is applied; therefore, sufficient preoperative preparation should be ensured (6). Moreover, the length of coils should be properly chosen, to avoid coil protrusion into the parent artery.

In conclusion, by studying this rare case of MMD associated with PcomA, we have gained insights into treatment plans and outcomes. A ruptured aneurysm in the proximal part of the PcomA needs to be treated promptly. If the ICA and PcomA are occluded accidentally, the patient may still have a good prognosis due to sufficient collateral blood circulation.

\section{REFERENCES}

1. Adams HP Jr, Kassell NF, Wisoff HS, Drake CG: Intracranial saccular aneurysm and moyamoya disease. Stroke 10:174179,1979

2. Czabanka M, Peña-Tapia P, Schubert GA, Heppner FL, Martus P, Horn P, Schmiedek P, Vajkoczy P: Proposal for a new grading of Moyamoya disease in adult patients. Cerebrovasc Dis 32:41-50, 2011

3. Ishii K, Fujiki M, Kobayashi H: Surgical management of moyamoya disease. Turk Neurosurg 18:107-113, 2008

4. Juvela S, Porras M, Poussa K: Natural history of unruptured intracranial aneurysms: Probability of and risk factors for aneurysm rupture. J Neurosurg 108:1052-1060, 2008

5. Kagawa K, Ezura M, Shirane R, Takahashi A, Yoshimoto T: Intraaneurysmal embolization of an unruptured basilar tip aneurysm associated with moyamoya disease. J Clin Neurosci 8:462-464, 2001

6. Lessne ML, Shah $P$, Alexander MJ, Barnhart HX, Powers CJ, Golshani K, Ferrell A, Enterline D, Zomorodi A, Smith T, Britz GW: Thromboembolic complications after Neuroform stent-assisted treatment of cerebral aneurysms: The Duke Cerebrovascular Center experience in 235 patients with 274 stents. Neurosurgery 69:369-675, 2011

7. Morioka M, Hamada J, Kawano T, Todaka T, Yano S, Kai Y, Ushio Y: Angiographic dilatation and branch extension of the anterior choroidal and posterior communicating arteries are predictors of hemorrhage in adult moyamoya patients. Stroke 34:90-95, 2003 
8. Moriyama $\mathrm{T}$, Teramoto $\mathrm{S}$, Kitajima $\mathrm{H}$, Yonekura $\mathrm{M}$, Fujii $\mathrm{H}$ : Moyamoya vessels associated with multiple cerebral aneurysms. Report of a surgically treated case and review of the literature. Neurol Med Chir (Tokyo) 26:160-166,1986

9. Satoh T, Yamamoto $Y$, Asari S, Sakurai M, Suzuki K: Disappearance and development of cerebral aneurysms in moyamoya disease. Case report. J Neurosurg 58:949-953, 1983
10. Waldron JS, Hetts SW, Armstrong-Wells J, Dowd CF, Fullerton HJ, Gupta N, Lawton MT: Multiple intracranial aneurysms and moyamoya disease associated with microcephalic osteodysplastic primordial dwarfism type II: surgical considerations. J Neurosurg Pediatr 4:439-444, 2009

11. Yeon JY, Kim JS, Hong SC: Incidental major artery aneurysms in patients with non-hemorrhagic moyamoya disease. Acta Neurochir (Wien) 153:1263-1270, 2011

12. Yu JL, Wang HL, Xu K, Li Y, Luo Q: Endovascular treatment of intracranial aneurysms associated with moyamoya disease or moyamoya syndrome. Interv Neuroradiol 16:240-248, 2006 